\title{
SETBP1 Gene
}

National Cancer Institute

\section{Source}

National Cancer Institute. SETBP1 Gene. NCI Thesaurus. Code C106635.

This gene may be involved in the modulation of protein SET activity. 